\title{
Leishmanicidal, cytotoxicity and wound healing potential of Arrabidaea chica Verlot
}

\author{
Joicy Cortez de Sá ${ }^{1 \dagger}$, Fernando Almeida-Souza ${ }^{2 \dagger}$, Renata Mondêgo-Oliveira ${ }^{3}$, lara dos Santos da Silva Oliveira ${ }^{1}$, \\ Lyah Lamarck ${ }^{3}$, Isadora de Fátima Braga Magalhães ${ }^{3}$, Aarão Filipe Ataídes-Lima ${ }^{4}$, Higor da Silva Ferreira ${ }^{4}$ \\ and Ana Lucia Abreu-Silva ${ }^{1,3^{*}+}$
}

\begin{abstract}
Background: Leishmaniasis includes a wide complex of diseases that affect humans and other mammals, and can range from a mild cutaneous form to a severe visceral type. The safety of the standard treatment using pentavalent antimony is a concern due to its toxic effects. The search for alternative, effective and less toxic treatments has led to the testing of natural products. The present study aimed to evaluate the cytotoxic, leishmanicidal and healing potential of Arrabidaea chica.

Methods: The crude ethanolic extract, as well as the chloroform, methanol and ethyl acetate fractions of $A$. chica were prepared and phytochemical analysis was performed. Cytotoxic evaluation was carried out through MTT colorimetric assay, and the $50 \%$ cellular cytotoxicity was determined. After that, the effect of the extract and fractions against Leishmania amazonensis promastigotes, at intervals of 24,48 and $72 \mathrm{~h}$, was analyzed, and $50 \%$ inhibitory concentration was determined. The healing effect of the plant was also tested in surgical lesions in Swiss mice skin.

Results: Phytochemical screening showed that the crude extracts contained flavonoids, tannins, anthocyanidins and chalcones. The leishmanicidal potential of $A$. chica produced satisfactory results in concentrations of between 60 and $155.9 \mathrm{\mu g} / \mathrm{mL}$. Cytotoxic assay revealed a $50 \%$ reduction in viable cells at a concentration of $189.9 \mathrm{\mu g} / \mathrm{mL}$. The healing results indicated that the treated group exhibited more pronounced signs of lesion resolution in the early period, but this pattern did not persist throughout the treatment.
\end{abstract}

Conclusions: The results of the present study demonstrate that $A$. chica has cytotoxic and leishmanicidal potential but its healing effect must be better studied.

Keywords: Arrabidaea chica, Cytotoxicity, Healing, Leishmanicidal activity

\section{Background}

Leishmaniasis is a group of diseases that affect several species of mammals that live in tropical and subtropical regions. Literature describes more than 20 species of the protozoan Leishmania that causes leishmaniasis, including cutaneous and visceral leishmaniasis $[1,2]$. These clinical forms differ in clinical presentation, morbidity and mortality [3].

\footnotetext{
* Correspondence: abreusilva.ana@gmail.com

${ }^{\dagger}$ Equal contributors

${ }^{1}$ Rede Nordeste de Biotecnologia, Universidade Estadual do Maranhão, São Luís, Brazil

${ }^{3}$ Programa de Pós-Graduação Mestrado em Ciência Animal, Universidade Estadual do Maranhão, São Luís, Brazil

Full list of author information is available at the end of the article
}

According to the World Health Organization, neglected diseases are those associated with low social indicators, and are thus more frequently found in developing countries where there is a lack of resources aimed at control and treatment and little research into finding an effective solution [4].

Among the clinical forms of the disease, the cutaneous, characterized by skin lesions, chiefly in exposed body parts, is the most common [5]. Depending on the species of Leishmania, in some patients leishmaniasis can heal without treatment, while in others diffuse cutaneous or mucocutaneous forms can develop [6].

In all clinical forms, pentavalent antimonials have been used as a mainstay therapy: the available drug for the treatment of leishmaniasis in the United States and Europe is sodium stibogluconate (Pentostam), while meglumine 
antimonate (Glucantime ${ }^{\circ}$ ) is more used in South America and Africa [7]. Despite this therapy having been widely employed since 1912, the mechanism of action is poorly understood and adverse effects, which include renal and hepatic toxicity, are severe [8]. Other limitations of this therapy are the necessity of daily parenteral administration and the resistance of the drug [2].

These limitations, the vast Brazilian biodiversity and traditional knowledge has led to the establishment of research networks to evaluate the leishmanicidal effect of plants from various biomes, such as the Cerrado and Amazon. It is therefore very important to perform experiments using natural products in order to identify new, less toxic, compounds which could be taken orally. In addition, the Brazilian government has created the RENISUS (Rede nacional de plantas medicinais de interesse do sistema único de saúde), a list of plants that can be used in the Unified Health Service, and Arrabidaea chica is included in this list.

Arrabidaea chica Verlot, popularly known as pariri, belongs to the Bignoniaceae Family, popularly known as pariri. It is endemic in almost all of Brazil but is most frequently found in the Amazon Forest [9] where it is used to treat skin disease, mulligrubs, anemia, jaundice and inflammatory reaction [10-12]. Widespread use by native populations lead researchers from different countries to evaluate the medicinal properties of this plant, including its anti-inflammatory [13]; astringent, antioxidant [14, 15]; anti-ulcer [16]; antimicrobial, antifungal $[17,18]$ and wound healing $[19,20]$ effects.

The aim of the present study was to evaluate the phytochemical effects, wound healing capacity and cytotoxicity of Arrabidaea chica, as well to evaluate the action of the crude extract and fractions of these plants on promastigotes of $L$. amazonensis.

\section{Methods}

\section{Ethics committee}

The experimental protocol for this study was approved by the ethics committee for animal research of the Universidade Estadual do Maranhão (CEUA-UEMA protocol 26/2009) and by the ethics committee in animal experimentation of Instituto Oswaldo Cruz - FIOCRUZ/ RJ (CEUA-FIOCRUZ protocol LW72/12).

\section{Plant}

Leaf and stem samples of Arrabidaea chica Verlot. were cultivated and collected in the Atico Seabra Herbarium, Departmento de Farmácia, Universidade Federal do Maranhão (São Luís, Maranhão, Brazil). The plant material was identified by Dr. Ana Zélia Silva and a voucher specimen was deposited under the number 1067. The plant material was collected between August and November 2011, which represents the dry season in this region, with a rainfall rate of $900 \mathrm{~mm}$ and an average temperature of $28^{\circ} \mathrm{C}$.

\section{Preparation of crude extract and fractions}

To obtain the crude ethanolic extract, the samples were dried at $40{ }^{\circ} \mathrm{C}$ with forced air circulation. The dried material from each part of $A$. chica was macerated and immersed in ethyl alcohol, in a proportion of 3:1 (alcohol and plant material, respectively). In order to obtain the ethanolic extracts solvent removal was carried out by rotoevaporation, under reduced pressure at 30 to $40{ }^{\circ} \mathrm{C}$, until the desired concentrations were achieved. The samples were stored under refrigeration and protected from light until analysis.

To determine the dry weight of the samples three aliquots of $0.5 \mathrm{~mL}$ of crude ethanolic extract were used. The yield of samples was calculated using the total weight of the powder, the dry weight obtained and the total final volume of the concentrated extract.

Additionally, the crude ethanolic extracts were fractionated by sequential partition using solvents of increasing polarity: chloroform, ethyl acetate and methanol. Extraction was carried out in the solid phase using silica gel, grail, pistil and approximately $500 \mathrm{~mL}$ of each solvent. Once obtained, the fractions were submitted to leishmanicidal and cytotoxic tests. Those that produced satisfactory results were sent to the Analytical Center of the Universidade de São Paulo (São Paulo, Brazil), to identify the bioactive compounds through gas chromatography and mass spectrometry.

\section{Phytochemical analysis}

To evaluate the presence of secondary metabolites (saponins, anthocyanidins, chalcones, phenols, tannins, flavonoids, steroids, triterpenoids and anthraquinones), crude ethanolic extracts of $A$. chica were solubilized in methanol (in a concentration of $100 \mathrm{mg} / 5 \mathrm{~mL}$ ), according to Costa and Matos [21, 22].

\section{In vitro cytotoxic assay Obtaining of peritoneal macrophages and cell culture}

Peritoneal macrophages were obtained from 4-week-old female BALB/c mice, from the Laboratory Animal Breeding Center (CECAL-FIOCRUZ) and kept in the Hélio and Peggy Pereira Pavilion animal facilitiy, located at the Oswaldo Cruz Foundation (FIOCRUZ, Rio de Janeiro, Brazil).

Three $\mathrm{mL}$ of $3 \%$ sodium thioglycollate was inoculated into the peritoneal cavity of the animals and, after $72 \mathrm{~h}$, were euthanized in a $\mathrm{CO}_{2}$ chamber. For macrophage recovery, $5 \mathrm{~mL}$ of a cold and sterile pH 7, 2 PBS solution was injected into the abdominal cavity, followed by massage and collection of lavage, which was kept in a falcon tube, placed in an icebox. After collection, the lavage was analyzed under an optical microscope to verify the 
presence of macrophages and the lack of red blood cells and bacteria.

Peritoneal lavage was centrifuged at $500 \mathrm{xg}$ for $10 \mathrm{~min}$ at $4{ }^{\circ} \mathrm{C}$. The supernatant was discarded and the cells resuspended in $1 \mathrm{~mL}$ of RPMI 1640 and counted in a Neubauer chamber. Final macrophage concentration was standardized at $5 \times 10^{5}$ cells/well. For cell culture, RPMI supplemented with $10 \%$ fetal bovine serum, L-glutamine $(20 \mathrm{mM})$, sodium bicarbonate solution $(7.5 \%)$, penicillin $(100 \mu \mathrm{g} / \mathrm{mL})$ and streptomycin $(50 \mu \mathrm{g} / \mathrm{mL})$ was used, incubated at $37^{\circ} \mathrm{C}$ with $5 \% \mathrm{CO}_{2}$.

\section{$\mathrm{CC}_{50}$ determination}

Cytotoxicity was measured by MTT colorimetric assay, in accordance with [23]. Briefly, $100 \mu \mathrm{L}$ of peritoneal macrophages $\left(5 \times 10^{5}\right.$ cells/well $)$ were added to 96 -well plates and incubated for $2 \mathrm{~h}$, at $37{ }^{\circ} \mathrm{C}$ with $5 \% \mathrm{CO}_{2}$. After that, $100 \mu \mathrm{L}$ of the crude ethanolic extracts or fractions of $A$. chica were added to the wells in serial concentrations (600 to $0.97 \mu \mathrm{L} / \mathrm{mL}$ ). For each concentration a negative control was maintained. Dimethyl sulfoxide (DMSO) was used as a control drug in serial dilutions starting at $20 \%$. After $24 \mathrm{~h}$ of incubation, $5 \mu \mathrm{L}$ of MTT [3-(4, 5-dimethylthiazol-2-yl)-2, 5-diphenyl tetrazolium bromide] was added to each well, then the plates were incubated again for $2-4 \mathrm{~h}$ under the same conditions. Later, they were centrifuged at $1500 \mathrm{xg}$ and $200 \mu \mathrm{L}$ of each well supernatant was discarded, before $100 \mu \mathrm{L}$ of DMSO was added. Absorbance was measured in a spectrophotometer, at a wavelength of $540 \mathrm{~nm} .50 \%$ cellular cytotoxicity $\left(\mathrm{CC}_{50}\right)$ was calculated using GraphPad Prism 5.

\section{In vitro antileishmanial activity \\ Parasites}

The present study used the Leishmania amazonensis (MHOM/BR/76/MA-76 - IOC/FIOCRUZ-RJ) strain, isolated from a patient with diffuse cutaneous leishmaniasis and maintained by serial passages in BALB/c mice, and periodically re-isolated in culture medium. Promastigote forms were grown at $26{ }^{\circ} \mathrm{C}$ in Schneider's medium, supplemented with $10 \%$ fetal bovine serum, streptomycin $(100 \mu \mathrm{g} / \mathrm{mL})$ and penicillin $(100 \mu \mathrm{g} / \mathrm{mL})$. To ensure infectivity only cultures of promastigote with a maximum of seven in vitro passages were used.

Before evaluation of leishmanicidal activity and determination of the $50 \%$ inhibitory concentration $\left(\mathrm{IC}_{50}\right)$ of $A$. chica, a screening test was performed to determine the concentration used in $\mathrm{IC}_{50}$ assay. The concentration used ranged between 500 and $0.97 \mu \mathrm{g}$ of crude ethanolic extracts or fractions, diluted in $1 \%$ DMSO, and added to 96-well plates containing RPMI, serially and in triplicate. Wells containing medium and parasites, medium only, and the reference drug, Amphotericin B $(2 \mu \mathrm{g} / \mathrm{mL})$, were used as controls. $100 \mu \mathrm{L}$ of $L$. amazonensis promastigotes in the logarithmic phase $\left(1 \times 10^{6}\right.$ parasites $\left./ \mathrm{mL}\right)$ were added to each well, and the plate was incubated at $26^{\circ} \mathrm{C}$. Parasite viability was measured after 24, 48 and $72 \mathrm{~h}$, by observing motility under an inverted microscope. The parasites were classified according to mobility on a scale of zero to ten, where zero means no viable forms and ten, viable forms.

Based on the screening results the $\mathrm{IC}_{50}$ was determined, following the same aforementioned protocol, and leishmanicidal activity was assessed by counting the viable parasites in a Neubauer chamber. The data was then normalized using the formula: Percentage of growth inhibition $=$ number of parasites in test wells/number of parasites in the control well, multiplied by 100; and used for statistical analysis.

\section{Wound healing activity Cream and therapeutic protocol}

Two topical preparations $(10 \mathrm{mg} / \mathrm{g}$ and $20 \mathrm{mg} / \mathrm{g}$ ) were prepared containing the crude ethanolic extract from $A$. chica leaves mixed with Lanette ${ }^{\bullet}$ cream, as a water-soluble anionic vehicle.

Forty 4-to-6 week old male Swiss Webster mice from the animal facility of the Universidade Estadual do Maranhão (São Luís, Maranhão, Brazil) were used in this experiment. The animals were randomly divided into two groups ( $n=20$ each). The control group was treated with Lanette ${ }^{\circ}$ cream and the experimental group was treated with Lanette ${ }^{\circ}$ cream containing the crude ethanolic extract of $A$. chica.

For creation of a dorsal skin wound, the animals were anesthetized with an intraperitoneal injection of xylazine hydrochloride (10 to $15 \mathrm{mg} / \mathrm{kg}$ ) and ketamine hydrochloride (100 to $150 \mathrm{mg} / \mathrm{kg}$ ). Trichotomy of the dorsal region and demarcation of the skin with a punch was then carried out. Resection of a circular segment of approximately $6 \mathrm{~mm}$ diameter was performed, exposing the dorsal fascia. Hemostasis was carried out by digital compression with sterile gauze, with treatment initiated immediately afterwards.

The therapeutic protocol was performed twice a day throughout the experimental period. Transverse and longitudinal diameters of the lesions were measured daily, using a digital caliper, and monitored through photography. Skin wound areas were calculated using the formula $\mathrm{A}=\pi \times \mathrm{R} \times \mathrm{r}$, in which $\mathrm{A}$ represents the area, $\pi$ is equal to 3.14, $\mathrm{R}$ represents the largest diameter and $\mathrm{r}$ the smallest diameter of the wound.

\section{Histological analysis}

After 3, 7, 14 and 21 days of treatment, the mice were euthanized and the lesions were excised with a margin of $1 \mathrm{~cm}$ of integrate skin, stored in $10 \%$ buffered formalin 
solution and submitted to histological procedures. After embedding in paraffin, $5 \mu \mathrm{m}$ thick cross sections were cut and stained with hematoxylin-eosin (HE) for morphological analysis of the tissue. Additionally, fragments of liver, spleen and kidney were collected, for evaluation of potential cytotoxic lesions.

Slides were analyzed by light microscopy by two independent examiners, following the parameters: crust formation, presence of inflammatory infiltrate, angiogenesis, reepithelialization and collagen formation [24]. These features were graded as absent, mild, moderate and severe, according to their appearance.

\section{Statistical analysis}

Statistical analysis was performed using GraphPad Prism 5.0.4 (GraphPad Software Inc.). $\mathrm{IC}_{50}$ and $\mathrm{CC}_{50}$ values were calculated from the mean percentage reduction of promastigotes and macrophages, respectively. Curves were determined by application of sigmoidal regression to logarithm concentration response data. In vitro results are representative of three different experiments, performed in triplicate, under the same temperature, $\mathrm{CO}_{2}$, time and culture medium conditions, with similar results. Analysis of wound healing was performed using the Student's t-test. Histological variables were analyzed by non-parametric test. Differences were considered significant at $P<0.05$.

\section{Results}

\section{Yield of extraction and phytochemical analysis}

The crude ethanolic extracts of Arrabidaea chica leaves and stem presented a yield of 59.2 and $3.33 \%$ respectively, which shows that the stem has a low extraction efficiency, as the same extraction method was used for both stem and leaves.

Phytochemical screening showed that both leaves and stem extracts contain flavonoids, tannins, anthocyanidins and chalcones. Phenolic compounds were found only in the leaves (Table 1).

Table 1 Phytochemical prospection of crude ethanolic extract of leaves and stem of Arrabidaea chica, collected in Maranhão state, Brazil

\begin{tabular}{llll}
\hline Metabolite class & Reactions & \multicolumn{2}{l}{ Arrabidaea chica } \\
\cline { 3 - 4 } & & Leaves & Stem \\
\hline Anthraquinones & $\mathrm{NaOH}$ & - & - \\
Flavonoids & $\mathrm{AlCl}_{3}$ & + & + \\
Triterpenes/steroids & Anhidrous acetic/ & - & - \\
Saponin & sulphuric acid & & - \\
Phenolic compound & $\mathrm{Foaming}^{2}$ & - & - \\
Tannin & FeCl & & + \\
Anthocyanidins/chalcones & $\mathrm{HCl} / \mathrm{NaOH}$ & + & + \\
\hline
\end{tabular}

(+) presence; (-) absence

\section{$\mathrm{IC}_{50}$ determination}

In screening tests to evaluate the potential leishmanicidal effect on L. amazonensis promastigotes, A. chica stem extract showed no activity against the protozoan, even at the highest tested concentration $(500 \mathrm{mg} / \mathrm{mL})$, and so was not used in continuity tests.

In the screening tests of the crude ethanolic extract of A. chica leaves, there was a reduction of $50 \%$ of L. amazonensis promastigote viability with a concentration of $125 \mu \mathrm{g} / \mathrm{mL}$ (Fig. 1) at the intervals of 24,48 and $72 \mathrm{~h}$ after incubation. However, the concentration of $250 \mu \mathrm{g} /$ $\mathrm{mL}$ displayed antileishmanial activity in the first $24 \mathrm{~h}$ of treatment and a total absence of viable parasites after $72 \mathrm{~h}$ of incubation. The concentration of $500 \mu \mathrm{g} / \mathrm{mL}$ of the leaf ethanol extract had the best leishmanicidal efficacy at the three tested intervals.

After screening, the $50 \%$ inhibitory concentration $\left(\mathrm{IC}_{50}\right)$ of $L$. amazonensis promastigote forms was determined as $155.9 \mu \mathrm{g} / \mathrm{mL}$ (Fig. 2).

When evaluating the leishmanicidal activity of the chloroform, methanol and ethyl acetate fractions, there was a $50 \%$ reduction of $L$. amazonensis promastigotes at concentrations of $120 \mu \mathrm{g} / \mathrm{mL}, 120 \mu \mathrm{g} / \mathrm{mL}$ and $60 \mu \mathrm{g} / \mathrm{mL}$, respectively (Table 2 ). This result demonstrated that the fractions acted against the parasite at lower concentrations than the crude extract, and that the ethyl acetate fraction had the most effective result.

\section{$\mathrm{CC}_{50}$ determination}

Cytotoxicity assay in the peritoneal macrophages after $24 \mathrm{~h}$ showed that a $189.9 \mu \mathrm{g} / \mathrm{mL}$ concentration of $A$. chica leaf extract reduced the number of viable cells by $50 \%$, representing $\mathrm{CC}_{50}$ (Fig. 3).

Regarding $\mathrm{CC}_{50}$ and $\mathrm{IC}_{50}$ values of the crude extract, it was observed that $A$. chica's bioactive compounds have a higher Selectivity Index (1.218) to the parasite than to the host cell, proving to be a potential treatment for leishmaniasis.

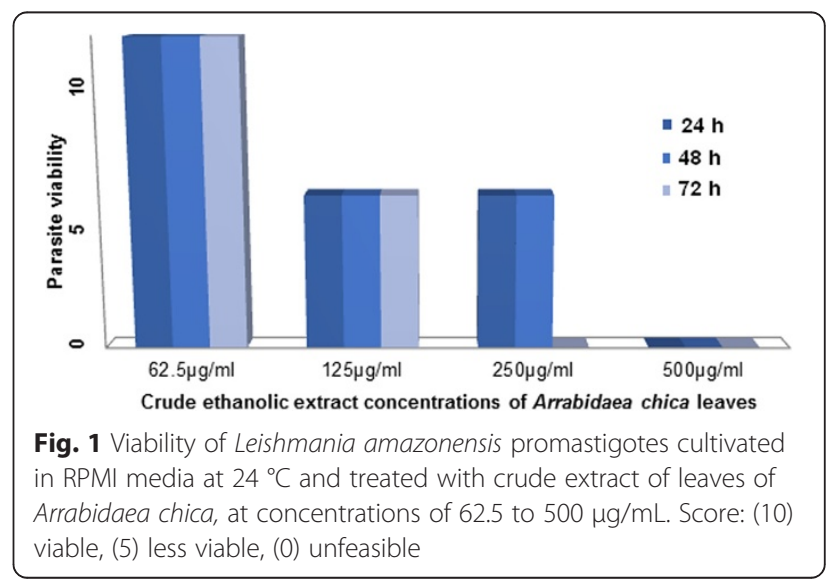




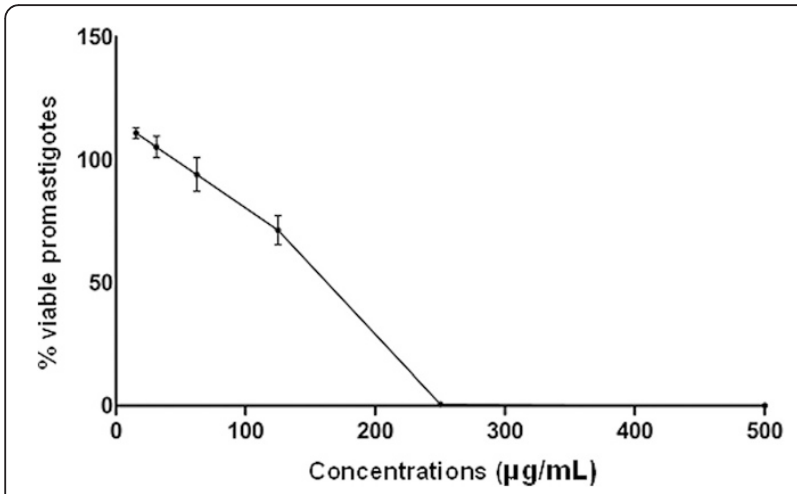

Fig. 2 In vitro leishmanicidal activity of the crude ethanolic extract of Arrabidaea chica against Leishmania amazonensis promastigotes at concentrations of 0.97 to $500 \mu \mathrm{g} / \mathrm{mL}$

\section{Healing effect}

Regarding the evaluation of dermal irritation potential of the crude extract of $A$. chica leaves, a concentration of $20 \mathrm{mg} / \mathrm{g}$ caused skin irritation, with the presence of moderate and persistent erythema during the treatment period. Thus, the healing test was performed with a concentration of $10 \mathrm{mg} / \mathrm{g}$.

In macroscopic analysis of the wound healing process, the beginning of the tissue repair process, with the presence of crusts on the third day, was noted. On the seventh day, a reduction in the size of the wound and the formation of granulation tissue in both the treated and control groups was observed (Fig. 4).

In the 0-3 day interval an increase in the lesion area was observed in the group treated with $A$. chica, as compared to the control group (Fig. 5). In the third to the 10th day, there was a marked reduction in the wound area, with a gradual approximation of the edges in both the control and treated groups.

Between the 14th and 21th post-injury days, the retraction of the wound was almost complete, with marked healing and tissue repair.

On the third day of treatment cellular debris and moderate to intense inflammatory process was observed in both groups. Discrete angiogenesis, collagen deposition

Table $250 \%$ inhibitory concentration ( $\left.\mathrm{IC}_{50}\right)$ of Leishmania amazonensis promastigote forms after $72 \mathrm{~h}$ treatment with crude ethanolic extract and chloroform, methanolic and ethyl acetate fractions of Arrabidaea chica

\begin{tabular}{ll}
\hline Treatments & $\mathrm{IC}_{50}(\mu \mathrm{g} / \mathrm{mL})$ \\
\hline Crude ethanolic fraction & $155.9 \pm 0.1185$ \\
Chloroform fraction & $>120$ \\
Methanolic fraction & $>120$ \\
Ethyl acetate fraction & $>60$ \\
Amphotericin B (reference drug) & $0.76 \pm 0.9218$
\end{tabular}

Values represent mean \pm standard deviation

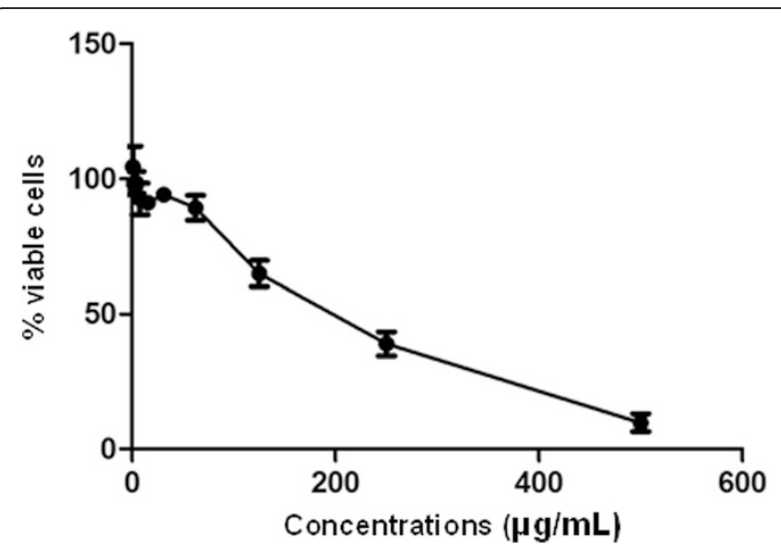

Fig. 3 Cytotoxicity evaluation in peritoneal macrophages cultured in RPMI medium, at $37^{\circ} \mathrm{C}$ and $5 \% \mathrm{CO} 2$ and treated for $24 \mathrm{~h}$ with ethanol extract of Arrabidaea chica leaves at concentrations of 0.97 to $500 \mu \mathrm{g} / \mathrm{mL}$

and epithelialization were observed in the treated group (Fig. 6a-b), as well as an increased amount of mast cells.

On the seventh day of treatment, re-epithelialization and the reduction of cell debris and the inflammatory process was quite evident. While there was no difference between the two groups, the patterns of re-epithelialization, angiogenesis and collagen deposition were higher in the control group.

Healing process evaluation between the 14th and 21st days showed epithelialization and intense collagen deposition in the control group (Fig. $6 c-d$ ), while the treated group (Fig. 6e-f) revealed patterns ranging from mild to intense. In both groups, there was a low number of inflammatory cells and mast cells. Angiogenesis was discreet in the treated group and varied from moderate to mild between the 14th and the 21 st day.

The topical preparation with the crude extract of $A$. chica at a concentration of $10 \mathrm{mg} / \mathrm{g}$ displayed a more effective healing activity in the initial phase of the experiment, but was not able to induce a stronger response throughout the 21 day observation period.

\section{Discussion}

Plants are important sources of bioactive compounds, and are a major potential source of new therapeutic agents against several diseases, including those of interest to public health, in particular neglected diseases such as leishmaniasis.

The bioactive compounds produced by plant cells may vary depending on soil, climate and the season that the plant, fruit or leaves were collected. Soil and climate conditions, along with the plant's need for adaptation and defense, bring about this change in chemical constituents [25]. Phytochemical analysis of $A$. chica revealed the presence of flavonoids, tannins, anthocyanidins, 


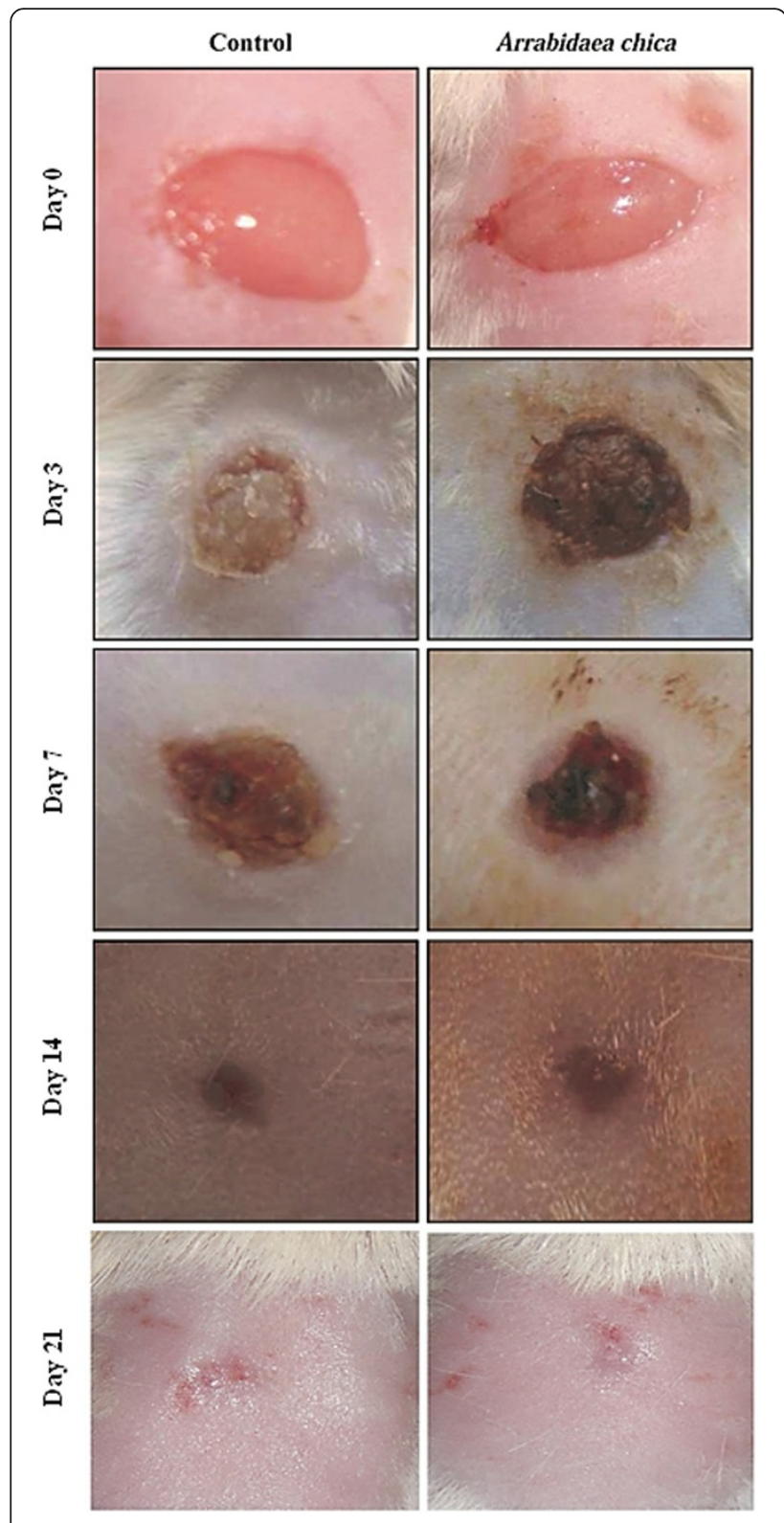

Fig. 4 Macroscopic evaluation of the healing process in Swiss mice Webster treated with LANETTE ${ }^{\circledR}$ cream (Control Group) and ethanol extract of Arrabidaea chica leaves (Experimental Group) over 21 days

chalcones and phenolic compounds, as previously described for this species [26, 27].

The first chemical study with the leaves of $A$. chica was performed by Chapman et al. and reported the isolation of the substance 3-deoxyanthocyanidin, more specifically 1,6,7-dihydroxy-5,4' -dimethoxy-flavylium (carajurin) and 6,7,4'-trihydroxy-5', methoxy-flavyluim (carajurone), responsible for the reddish color of the extract [28]. In other studies, other compounds, such as flavone acacetin, oleanolic triterpene acid and two deoxiantocyanidins $\left(6,7,3^{\prime}\right.$ 4'-tetrahydroxy-5-methoxy-flavylium and 6, 7, 3'-trihydroxy-5, 4' dimethoxy-flavyliume) were isolated [29-31].
Anthocyanins are plant pigments belonging to the family of flavonoids, included in the group of phenolic compounds $[32,33]$. More than 50 new anthocyanins have been isolated from the flowers, fruits, seeds and leaves of plants. They play a pivotal role in flower pollination, seed dispersal by insects and defense against predatory insects [34].

Pharmacological studies with anthocyanins reveal their high antioxidant effect [15] on metabolic diseases [35]. The antioxidant, cytotoxic, antimicrobial and diuretic potential of the ethanol extract and fractions of $A$. chica was evaluated by Amaral et al. that confirmed this antioxidant and diuretic action, and the absence of an antimicrobial and cytotoxic response [14]. The therapeutic activity of the phenolic compounds is mainly attributed to their antioxidant capacity, the chelation of metal ions, modulation of gene expression and interaction with cell signaling pathways [36].

Phenolic composition and antioxidant activity of the leaves of $A$. chica was evaluated by Siraichi et al. by liquid chromatography-electrospray ionization-tandem mass spectrometry (LC-ESI-MS/MS), and verified the presence of two important flavonoids, apigenin and scutellarein, which are most responsible for the significant antioxidant action [15].

In pharmacological tests, Alves et al. determined the chemical potential of $A$. chica dye, which is widely used by indigenous tribes, and verified the presence of alkaloids, anthocyanidins, anthocyanins, anthraquinone, steroids, triterpenoids, phenols, flavanonois, flavanols, flavanones, saponins and catechin tannin [37]. This study described some compounds undetected in the present study, differing in the presence of anthraquinones, steroids, triterpenoids and saponins. This fact is probably due to the climate differences between the two places where the plant was collected, the states of Maranhão and Pará, as well as the method by which the extract was obtained. Both were obtained using ethanol as a solvent; however, in the present study this was submitted to $72 \mathrm{~h}$ rotoevaporation at $40{ }^{\circ} \mathrm{C}$, while in the aforementioned study the extract was macerated for 10 days in a capped percolator.

In vitro pharmacological studies have demonstrated the antineoplasic and antioxidant potential of $A$. chica, and this action was directly related to the high content of flavonoids, especially anthocyanins [38]. These and other benefits made the search for new sources of anthocyanins essential [35].

The secondary metabolites in $A$. chica, such as flavonoids, the antimicrobial, antiviral, anti-inflammatory, antineoplastic, antifungal and anti-protozoan action of which has already been reported in literature [17, 38-40], encourages many researchers to study this plant.

In the present study, the leishmanicidal potential of the crude extract and fractions of A. chica, which displayed satisfactory results at concentrations between 60 


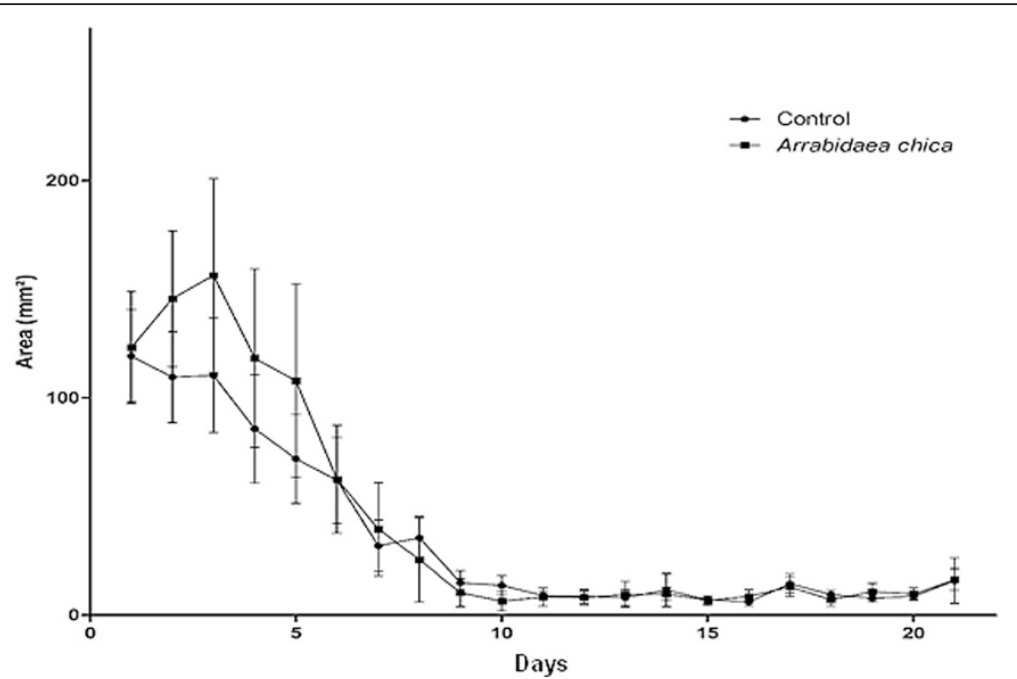

Fig. 5 Wound healing kinetics of surgical lesions in Swiss Webster mice treated with Lanette ${ }^{\oplus}$ cream (Control Group) and ethanol extract of Arrabidaea chica leaves (Experimental Group) over 21 days

and $155.9 \mu \mathrm{g} / \mathrm{ml}$, depending on the type of fraction. The chemical constituents of the plant were more selective for the protozoan than the host cell, with a cytotoxicity effect at concentrations higher than those with leishmanicidal action.

Several studies have aimed to identify and characterize crude extracts, fractions and essential oils [41-48], as well as the isolated compounds of the plant $[49,50]$, with leishmanicidal activity. The screening of these natural compounds is performed with cultures of Leishmania spp., as it is easy to maintain and produce [51].

According to the World Health Organization, a candidate drug must undergo in vitro cytotoxicity and antiparasitic activity testing. After this initial screening, the results are evaluated to define the continuity of studies and the possibility of in vivo assays [52].

Studies performed by Rodrigues et al. [53] investigated the leishmanicidal effect of five fractions obtained from the crude hexane extract of $A$. chica, on L. amazonensis and $L$. infantum promastigote forms, by determining the minimum inhibitory concentration (MIC), which was found to be 37.2 and $18.6 \mu \mathrm{g} / \mathrm{ml}$, respectively. This result is related to one of the fractions used, the main chemical components of which were linoleic acid methyl ester (25.38 \%), n-hexadecanoic acid (19.61\%), octadecanoic acid $(14.10 \%)$ and gamma-sitosterol (12.85 \%). The study also evaluated ultrastructural alterations of the parasite under the influence of this fraction, and observed mitochondrial swelling, disruption of mitochondrial membrane, presence of vesicles in the cytoplasm, mitochondria and flagellar pocket and modifications in the Golgi complex.

The significant increase in studies of plant compounds with leishmanicidal potential is due to of the major importance of this disease, of which there are large numbers of new cases annually. According to the World Health Organization 1.3 million new cases are recorded per year, being 300,000 cases of visceral leishmaniasis and 1 million cutaneous leishmaniasis [5].

Leishmaniasis are characterized as neglected diseases, as they are associated with low social indicators and are more prevalent in developing countries, whose resources in the areas of control, treatment and research are insufficient [4].

Additionally, plant extracts or plant compounds can represent a valuable source of new medicinal agents and alternative, effective and less toxic treatments, compared to conventional drugs (pentavalent antimoniates, amphotericin B, pentamidine), leading to a search for natural products with a potential leishmanicidal action. Furthermore, the benefits obtained from the search for natural products have encouraged interest in valuable synthetic compounds [42].

The crude extract from the leaves of $A$. chica had a cytotoxic effect at a concentration of $189.9 \mu \mathrm{g} / \mathrm{mL}$. Maliofete et al. [54], also testing the ethanol extract from the leaves of $A$. chica, observed low oral toxicity, absence of cytotoxicity and antibacterial activity against Helicobacter pylori. In vivo experimental studies did not show any clinical or histopathological signs of extract toxicity in the pleura [13], open or sutured wounds or burns [55]. Studies by Barbosa et al., assessing the antifungal, antimicrobial and antiprotozoal potential of the ethanolic extract and fractions of A. chica, observed growth inhibition of Trichophyton mentagrophytes and a significant trypanocidal effect against Trypanosoma cruzi, as well as the absence of relevant acute toxicity, even at the highest dose tested $(1000 \mathrm{mg} / \mathrm{kg})$ [17]. 


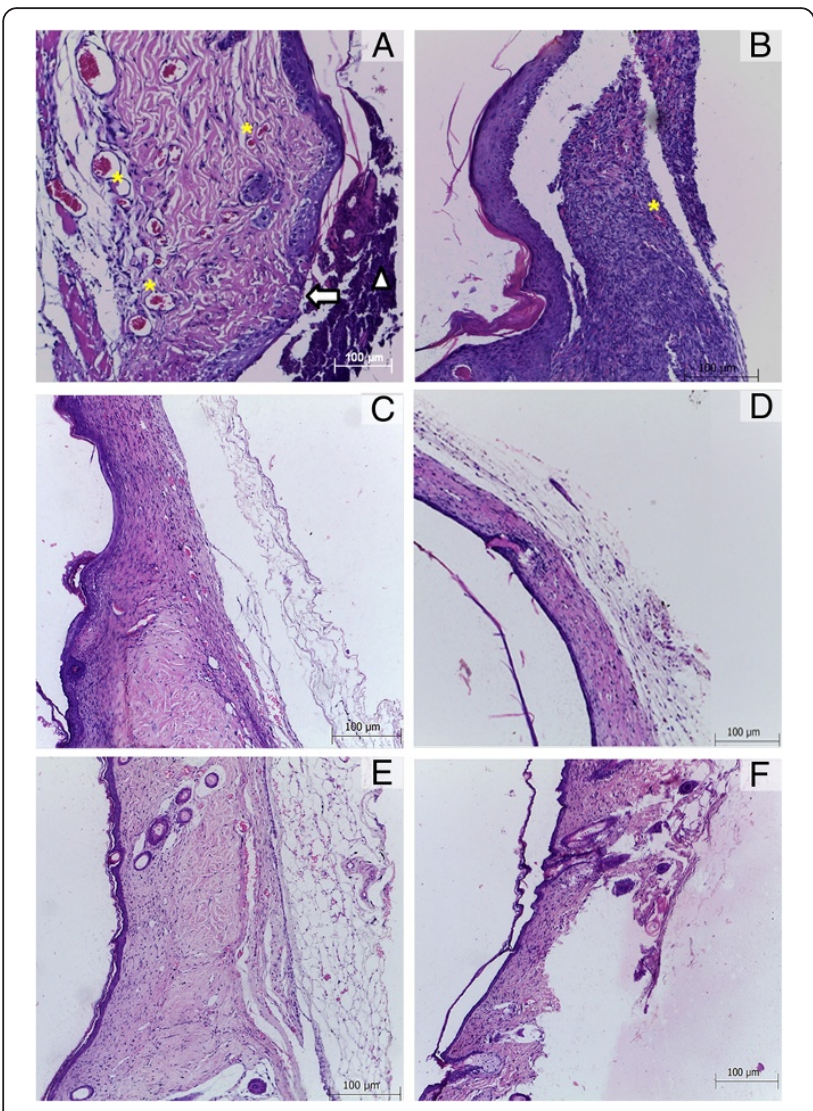

Fig. 6 Swiss Webster. Skin. Healing process through topical treatment with a cream containing the crude ethanolic extract of $A$. chica (experimental group) or only Lanette ${ }^{\circledR}$ cream (control group). a (3 days) - Experimental group: cellular debris $(\Delta)$, reepithelization (arrow), angiogenesis $\left({ }^{*}\right)$. b (7 days) - Experimental group: Absence of cellular debris and angiogenesis $\left(^{*}\right)$. c (14 days) and (d) (21 days) - Control group: Absence of cellular debris and reepithelization. e (14 days) and (f) (21 days) - Experimental group: Absence of cellular debris and reepithelization. HE

Several factors must be taken into consideration when evaluating the toxic effects of a plant extract, such as seasonal and environmental factors, the genotypic variations of the species, the part of the plant used to produce the extract, the time of collection and the age of the plant [25].

In traditional medicine in the Amazon region, $A$. chica is widely used as an anti-inflammatory, healing and antianemic medicine, and is prepared from the leaves as a tea, for oral or vaginal administration $[16,17,56]$. However, despite its wide popular use, several studies are still necessary to evaluate the medical potential of this plant.

In the present study, the healing potential of the crude extract of the leaves of $A$. chica in skin lesions was evaluated. A satisfactory response was initially observed, with angiogenesis and collagen deposition, but over the 21-day observation period it was found that the extract did not accelerate healing, presenting a similar profile to the control group.
Several local and systemic factors can cause variations in the healing process, leading to a delay or even prolongation of healing. Among these are the local of the lesion, existence of infection, surgical technique, tissue ischemia and bandages, as well as malnutrition and/or deficiency of trace minerals and vitamins $[57,58]$.

As cited above the importance of bandages in the healing process should be noted. Several studies have demonstrated that there the healing process is more successful when bandages are placed on the location of the wound after the application of the test product $[16,59]$ to protect the injury area. This step, which was not performed in the present study, may have contributed to the retardation of healing. The application of a suitable compress enables an increase of the natural debridement and simplifies healing, as it keeps the exudates rich on mediators on the wound surface [60].

Wound healing is a complex and dynamic process of the replacement of a devitalized tissue by a new tissue, which occurs through a series of biochemical cascade events; usually divided into three phases: the inflammatory, proliferative, and remodeling phases [61]. Wound healing treatment has improved considerably over time, notably in order to achieve the best scarring results in the shortest possible time.

In the present study, a strong inflammatory response was observed at the beginning of the healing process, with an increased lesion area until the 3rd day after surgical incision and the presence of inflammatory cells in histological evaluation. The inflammatory phase is characterized by increased vascular permeability and immune cells chemotaxis to the site of injury, due to the release of mediators (histamine, serotonin, bradykinin, prostaglandins, thromboxanes) [62].

The most pronounced reduction period in the wound area was between the third and the 10th day, with retraction of the wound area, representing the proliferative phase. During this phase fibroplasia, granulation tissue formation, and removal of cellular debris were observed, with the formation of a temporary repair tissue during inflammation, and development of tissue substitutes [63].

In the healing process, fibroplasia occurs together with neovascularization [61]. As the wound healing process advances, fibroblasts undergo phenotypic changes, with an abundance of rough endoplasmic reticulum, due to intense protein synthesis; and subsequent transformation into myofibroblasts, which help in the retraction of the lesion [64, 65].

Studies performed by Jorge et al. [16], when evaluating the healing, anti-inflammatory, antiulcerogenic and antioxidant effect of crude methanolic extract of $A$. chica, found that there was no reduction of paw edema induced by carrageenan or ear edema induced by croton oil in rats. However, in vitro fibroblast proliferation induction, stimulation 
of collagen synthesis in vivo and in vitro, anti-ulcer activity and moderate antioxidant capacity were observed.

After 10 days, it was verified that $96 \%$ of wounds in the experimental group had healed, with a prominent collagen deposition, while in the control group, treated with saline solution, only $36 \%$ of the wounds had healed, with a mild collagen deposition [16].

The topic healing effect of $A$. chica extract in the tendons of Wistar rats was investigated by Aro et al., that found better collagen organization in the treated groups than in the control group, as well as an increase in sulfate, on the 14th day treatment [20].

Compounds exhibiting antioxidant activity can indicate good therapeutic agents in the healing process, according to Houghton et al. [57]. Non-enzymatic antioxidant activity is promoted by flavonoids, carotenoids, ascorbic acid, glutathione, and vitamin E, among others [58, 66, 67]. Therefore, the healing activity of A.chica is attributed to the antioxidant activity of anthocyanins and to fibroblast proliferation stimuli and consequent collagen synthesis $[16,68]$.

Fibroblasts are connective tissue cells, essential for dermis formation, due to collagen production, and responsible for structural firmness. After tissue injury, fibroblasts near the lesion site proliferate, migrate to the wound and produce a large amount of matrix material rich in collagen (type I and III), which helps to isolate and repair the injured tissue [63].

The proliferation of fibroblasts is directly related to the presence of macrophages in the healing process, as these release growth factors and cytokines essential for the maturation of the inflammatory phase and the beginning of the healing. Among the growth factors responsible for the proliferation, insulin-like growth factor 1 (IGF-I) and transforming growth factor beta (TGF- $\beta$ ) play an important role. Studies have demonstrated that IGF-I increases the procollagen chain expression in cultured dermal fibroblasts [63].

In the present study, on day 14 the control and experimental groups presented a smaller healing area than on day 07. At the end of the experiment, after 21 days, both groups were in the final stages of the healing process, in which the remodeling phase predominates, characterized by the reduction of inflammatory cells [69] and blood vessels at the lesion site [61], being the stage in which the scar acquires maximum resistance [70].

Several plants are used in popular medicine for the treatment of skin disorders. A number of these, such as Aloe vera ("babosa"), Schinus terebenthifolius ("aroeira"), Stryphnodendrom barbatiman ("barbatimão"), Calendula officinalis ("calendula") and Triticum vulgare ("trigo") are especially worthy of note due to the number of Brazilian studies involving the phytopharmaceutical use of these species [71-74].

\section{Conclusions}

The present study demonstrates that the compounds extracted from A. chica leaves are potential leishmanicidal agents in non-cytotoxic concentrations, with further research required to continue the evaluation of this potential, in order to develop new drugs based on these compounds, or associate them with drugs already used in therapeutic protocols for the disease. The wound healing potential of the plant requires additional studies, in order to eliminate the interference of external factors and optimize the action of $A$. chica extract.

\section{Abbreviations \\ ${ }^{\circ} \mathrm{C}$ : Celsius degree; $\mu \mathrm{g} / \mathrm{mL}$ : microgram per milliliter; $\mu \mathrm{L}$ : microliter; $\mu \mathrm{m}$ : micrometer; $\mu \mathrm{M}$ : micromolar; $\mathrm{AlCl}_{3}$ : Aluminum chloride; ANOVA: Analysis of variance; \\ $\mathrm{CC}_{50}$ : 50 \% cellular cytotoxicity; $\mathrm{CO}_{2}$ : Carbon dioxide; DMSO: Dimethyl sulfoxide; $\mathrm{FeCl}_{3}$ : Iron chloride; FGF2: Fibroblast growth factor 2; G: giros; HCl: Hydrochloric acid; HE: Hematoxylin-eosin; $I_{50}$ : 50 \% inhibitory concentration; IGF-I: Insulin-like growth factor 1; mg/kg: milligrams per kilogram; $\mathrm{mg} / \mathrm{mL}$ : milligrams per milliliter; mM: millimolar; MTT: (3-[4,5- dimethylthiazol-2-yl]-2,5-diphenyl tetrazolium bromide); $\mathrm{NaOH}$ : Sodium hydroxide; PBS: Phosphate buffered saline; RPMI: Roswell Park Memorial Institute medium; TGF- $\beta$ : Transforming growth factor beta.}

\section{Competing interests}

The authors declare that they have no competing interests.

\section{Authors' contributions}

JCS and FAS performed phytochemical analysis, leishmanicidal and cytotoxic assays, and made substantial contributions to the conception of the study and the acquisition and interpretation of data. RMO, ISSO, IFBM and LL contributed to the interpretation of data and the review and editing of the manuscript. AFAL and HSF collected the plant material, prepared the extracts and contributed to the interpretation of data. ALAS conceived the study, and participated in its design and coordination and helped to draft the manuscript. All the authors read and approved the final manuscript.

\section{Acknowledgements}

This work was supported by CNPq (Conselho Nacional de Desenvolvimento Científico e Tecnológico - grant 552536/2010-5), FAPEMA (Fundação de Amparo à Pesquisa e ao Desenvolvimento Científico e Tecnológico do Maranhão) and PROCAD NF (Programa Nacional de Cooperação Acadêmica - grant 0681/10). Ana L. Abreu-Silva is a CNPq senior researcher.

\section{Author details}

${ }^{1}$ Rede Nordeste de Biotecnologia, Universidade Estadual do Maranhão, São Luís, Brazil. ${ }^{2}$ Laboratório de Imunomodulação e Protozoologia, Fundação Oswaldo Cruz, Rio de Janeiro, Brazil. ${ }^{3}$ Programa de Pós-Graduação Mestrado em Ciência Animal, Universidade Estadual do Maranhão, São Luís, Brazil. ${ }^{4}$ Curso de Medicina Veterinária, Universidade Estadual do Maranhão, São Luís, Brazil. ${ }^{5}$ Departamento de Patologia, Universidade Estadual do Maranhão, São Luís, Brazil.

Received: 7 May 2015 Accepted: 15 December 2015 Published online: 04 January 2016

References

1. Bello ML, Chiaradia LD, Dias LR, Pacheco LK, Stumpf TR, Mascarello A, et al. Trimethoxychalcone derivatives inhibit growth of Leishmania braziliensis: synthesis, biological evaluation, molecular modeling and structure activity relationship (SAR). Bioorg Med Chem. 2011;19:5046-52.

2. Plano D, Baquedano $Y$, Moreno-Mateos D, Font M, Jiménez-Ruiz A, Palop JA, et al. Selenocyanates and diselenides: a new class of potent antileishmanial agents. Eur J Med Chem. 2011;46:3315-22.

3. Kheirandish F, Sharafi AC, Kazemi B, Bandehpour M, Tarahi MJ, Khamesipour A. First molecular identification of Leishmania species in a new endemic area of cutaneous leishmaniasis in Lorestan, Iran. Asian Pac J Trop Med. 2013;6:713-7. 
4. Mashayekhi-Ghoyonlo V, Kiafar B, Rohani M, Esmaeili H, Erfanian-Taghvaee MR. Correlation between socioeconomic status and clinical course in patients with cutaneous leishmaniasis. J Cutan Med Surg. 2015;19:40-4.

5. World Health Organization: Leishmaniasis. http://www.who.int/mediacentre/ factsheets/fs375/en/ (2015). Accessed 23 Apr 2015.

6. Teles CBG, Moreira LS, Silva AAE, Facundo VA, Zuliani JP, Stábeli RG, et al. Activity of the lupine isolated from Combretum leprosum against Leishmania amazonensis promastigotes. J Braz Chem Soc. 2011;22:936-42.

7. Lima EB, Porto C, Motta JCO, Sampaio RNR. Tratamento da leishmaniose tegumentar Americana. An Bras Dermato. 2007:82:111-24.

8. Frézard F, Demicheli C, Ribeiro RR. Pentavalent antimonials: new perspectives for old drugs. Molecules. 2009;14:2317-36.

9. Von Poser GL, Schripsema J, Henriques AT, Jensen AR. The distribution of iridoids in Bignoniaceae. Biochem Syst Ecol. 2000;28:351-66.

10. Gentry AH. A synopsis of Bignoniaceae ethnobotany and economic botany. Ann Missouri Bot Gard. 1992;79:53-64.

11. Rêgo TJA. Fitogeografia das plantas medicinais no Maranhão. 2nd ed. São Luís: EDUFMA; 1995.

12. Kalil Filho AN, Kalil GPC, Luz AIR. Conservação de germoplasma de plantas aromáticas e medicinais da Amazônia brasileira para uso humano. Ministério da Agricultura e do Abastecimento: Comunicado Técnico. EMBRAPA. 2000;50:1-4.

13. Oliveira DPC, Borrás MRL, Ferreira LCL, López-Lozano JL. Anti-inflammatory activity of the aqueous extract of Arrabidaea chica (Humb. \& Bonpl.) B. Verl. on the self-induced inflammatory process from venoms amazonians snakes. Rev Bras Farmacogn. 2009;19:643-9.

14. Amaral RR, Santos $A A D$, Saraiva $A$, Botas GS, Cruz RAS, Fernandes $C P$, et al. Biological activities of Arrabidaea chica (Bonpl.) B. Verl. leaves. Lat Am J Pharm. 2012;31:451-5.

15. Siraichi JTG, Felipe DF, Brambilla LZS, Gatto MJ, Terra VA, Cecchini AL, et al. Antioxidant capacity of the leaf extract obtained from Arrabidaea chica cultivated in southern Brazil. PLoS One. 2013;8(8):e72733. doi:10.1371/ journal.pone.0072733.

16. Jorge MP, Madjarof C, Gois Ruiz AL, Fernandes AT, Ferreira Rodrigues RA, de Oliveira Sousa IM, et al. Evaluation of wound healing properties of Arrabidaea chica Verlot extract. J Ethnopharmacol. 2008:118:361-6.

17. Barbosa WLR, Pinto LN, Quignard E, Vieira JMS, Silva Junior JOC, Albuquerque S. Arrabidaea chica (HBK) Verlot: phytochemical approach, antifungal and trypanocidal activities. Rev Bras Farmacogn. 2008;18:544-8.

18. Ferreira FAG, Carvalho CM, Costa JC, Ferreira JMR. Comprovação do potencial medicinal de Arrabidaea chica (Bignoniaceae). Sci Prim. 2013;1:1-6.

19. Lima RMS, Santos AMN, Jardim MAG. Levantamento de plantas tóxicas em duas comunidades caboclas do estuário amazônico. Bol Mus Para Emílio Goeldi. 1995;11:255-63.

20. Aro AA, Freitas KM, Foglio MA, Carvalho JE, Dolder H, Gomes L, et al. Effect of the Arrabidaea chica extract on collagen fiber organization during healing of partially transected tendon. Life Sci. 2013:92:799-807.

21. Costa AF. Farmacognosia. Lisboa: Fundação Calouste Gulbenkian; 1982.

22. Matos FJA. Introdução à Fitoquímica experimental. Fortaleza: Edições UFC; 1997.

23. Mosmann T. Rapid colorimetric assay for cellular growth and survival. J Immunol Methods. 1983;65:55-63.

24. Torres-Nunes J, Sousa de Araújo K, Medeiros de Melo Neto P. Estudo histológico da cicatrização de feridas cutâneas utilizando o leite colostro. ConScientiae Saúde. 2012;11:377-82.

25. Gobbo-Neto L, Lopes NP. Plantas medicinais: fatores de influência no conteúdo de metabólitos secundários. Quím Nova. 2007;30:374-81.

26. Scogin R. Anthocyanins of the Bignoniaceae. Biochem Syst Ecol. 1980;8:273-6.

27. Puhl MCMN, Serra LZ, Gutierre MAM, Cortez DAG, Sidrim JJC, Diogenes MJN, et al. Dermatofitoses. In: Sidrim JJC, editor. Fundamentos Clínicos e laboratoriais da micologia médica. Rio de Janeiro: Guanabara Koogan; 1999. p. 108-31.

28. Chapman E, Perkin AG, Robinson R. As matérias corantes de carajura. J Chem Soc. 1927;2:3015-41.

29. Takemura OS, Linuma M, Tosa H, Miguel OG, Moreira EA, Nozawa Y. A flavone from leaves of Arrabidaea chica f. CUPREA. Phytochemistry. 1995;38: 1299-300.

30. Zorn B, García-Piñeres AJ, Castro V, Murillo R, Mora G, Merfort I. 3Desoxyanthocyanidins from Arrabidaea chica. Phytochemistry. 2001;56:831-5.

31. Devia B, Llabres G, Wouters J, Dupont L, Escribano-Bailon MT, de PascualTeresa S, et al. New 3-Deoxyanthocyanidins from leaves of Arrabidaea chica. Phytochem Anal. 2002;13:114-9.
32. Taiz L, Zeiger E. Fisiologia vegetal. Porto Alegre: Artmed; 2004.

33. Williams CA, Grayer RJ. Review anthocyanins and other flavonoids. Nat Prod Rep. 2004;21:539-73.

34. Kong JM, Goh NK, Chia LS, Chia TF. Recent advances in traditional plant drugs and orchids. Acta Pharmacol Sin. 2003;24:7-21.

35. Zafra-Stone S, Yasmin T, Bagchi M, Chatterjee A, Vinson JA, Bagchi D. Berry anthocyanins as novel antioxidants in human health and disease prevention. Mol Nutr Food Res. 2007;51:675-83.

36. Soobrattee MA, Neergheen-Bhujun SV, Luximon-Ramma A, Aruoma O, Bahorun T. Phenolics as potential antioxidant therapeutic agents: mechanism and actions. Fundam Mol Mech Mutagen. 2005;579:200-13.

37. Alves MSM, Mendes PC, Vieira JGP, Ozela EF, Barbosa WLR, Silva Junior JOC. Análise farmacognóstica das folhas de Arrabidaea chica (Humb. \& Bonpl.) B. Verlt., Bignoniaceae. Rev Bras Farmacogn. 2008;20:215-21.

38. Ribeiro AFC, Telles TC, Ferraz VP, Sousa-Fagundes EM, Cassali GD, Carvalho AT, et al. Effect of Arrabidaea chica extracts on the Ehrlich solid tumor development. Rev Bras Farmacogn. 2012;22:364-73.

39. Zuanazzi JAS, Mountain JA. Flavonoides. In: Simōes CMO, Schenkel EP, Gossmann G, Mello JCP, Mentz LA, Petrovick PR, editors. Farmacognosia: da planta ao medicamento. 5th ed. Porto Alegre: Editora da Unversidade UFRGS; 2003. p. 577-614.

40. Tasdemir D, Kaiser M, Brun R, Yardley V, Schmidt TJ, Tosun F, et al. Antitrypanosomal and antileishmanial activities of flavonoids and their analogues: in vitro, in vivo, structure-activity relationship, and quantitative structure-activity relationship studies. Antimicrob Agents Chemother. 2006; 50:1352-64.

41. Weniger B, Vonthron-Sénécheau C, Arango GJ, Kaiser M, Brun R, Anton R. A bioactive biflavonoid from Campnosperma panamense. Fitoterapia. 2004; 75:764-7.

42. Rocha LP, Almeida JR, Macêdo RO, Barbosa-Filho JM. A review of natural products with antileishmanial activity. Phytomedicine. 2005;12:515-35.

43. Costa EV, Pinheiro ML, Xavier CM, Silva JR, Amaral AC, Souza AD, et al. A pyrimidine- $\beta$-carboline and other alkaloids from Annona foetida with antileishmanial activity. J Nat Prod. 2006;69:292-4.

44. Braga FG, Bouzada ML, Fabri RL, de O Matos M, Moreira FO, Scio E, et al. Antileishmanial and antifungal activity of plants used in traditional medicine in Brazil. J Ethnopharmacol. 2007;111:396-402.

45. Ferreira VF, Pinto AC. A fitoterapia no mundo atual. Quím Nova. 2010:33:1829.

46. Tiuman TS, Ueda-Nakamura T, Cortez DAG, Dias Filho BP, Morgado-Díaz JA, Souza W, et al. Antileishmanial activity of parthenolide, a sesquiterpene lactone isolated from Tanacetum parthenium. Antimicrob Agents Chemother. 2005:49:176-82.

47. Santos AO, Ueda-Nakamura T, Dias Filho BP, da Veiga Junior VF, Nakamura CV. Copaiba oil: an alternative to development of new drugs against leishmaniasis. Evid Based Complement Alternat Med. 2012;2012:898419. doi:10.1155/2012/898419.

48. Ribeiro TG, Chávez-Fumagalli MA, Valadares DG, Franca JR, Lage PS, Duarte $M C$, et al. Antileishmanial activity and cytotoxicity of Brazilian plants. Exp Parasitol. 2014;143:60-8.

49. Colares AV, Almeida-Souza F, Taniwaki NN, Souza C da S, da Costa JG, Calabrese $\mathrm{K}$ da S, et al. In vitro antileishmanial activity of essential oil of Vanillosmopsis arborea (Asteraceae) Baker. Evid Based Complement Alternat Med. 2013:2013:727042. doi:10.1155/2013/727042.

50. Rottini MM, Amaral AC, Ferreira JL, Silva JR, Taniwaki NN, Souza C da S, et al. In vitro evaluation of (-)a-bisabolol as a promising agent against Leishmania amazonensis. Exp Parasitol. 2015;148:66-72.

51. Fumarola L, Spinelli R, Brandonisio O. In vitro assays for evaluation of drug activity against Leishmania spp. Res Microbiol. 2004;155:224-30.

52. Dias LC, Dessoy MA, Silva JJN, Thiemann OH, Oliva G, Andricopulo AD. Quimioterapia da Doença de Chagas: estado da arte e perspectivas no desenvolvimento de novos fármacos. Quim Nova. 2009;32:2444-57.

53. Rodrigues JCF, Godinho JLP, De Souza W. Biology of human pathogenic trypanosomatids: epidemiology, lifecycle and ultrastructure. Subcell Biochem. 2014;74:1-42.

54. Mafioleti L, da Silva Junior IF, Colodel EM, Flach A, Martins DT. Evaluation of the toxicity and antimicrobial activity of hydroethanolic extract of Arrabidaea chica (Humb. \& Bonpl.) B. Verl. J Ethnopharmacol. 2013;150:576-82.

55. Oliveira F, Akisue K, Akisue MK. Farmacognosia. São Paulo: Atheneu; 1998.

56. Borrás MRL. Plantas da Amazônia: medicinais ou mágicas? Plantas comercializadas no Mercado Municipal Adolpho Lisboa. Manaus: Valer/ Governo do Estado do Amazonas; 2003. 
57. Houghton PJ, Hylands PJ, Mensah AY, Hensel A, Deters AM. In vitro tests and ethnopharmacological investigations: wound healing as an example. J Ethnopharmacol. 2005;100:100-7.

58. Perez Gutierrez RM, Vargas RS. Evaluation of the wound healing properties of Acalypha langiana in diabetic rats. Fitoterapia. 2006;77:286-9.

59. Panchatcharam M, Miriyala S, Gayathri VS, Suguna L. Curcumin improves wound healing by modulating collagen and decreasing reactive oxygen species. Mol Cell Biochem. 2006;290:87-96.

60. Hosgood G. Stages of wound healing and their clinical relevance. Vet Clin North Am Small Anim Pract. 2006;36:667-85.

61. Young A, McNaught CE. The physiology of wound healing. Surgery. 2011;29: 475-9.

62. Mandelbaum SH, Di Santis EP, Mandelbaum MHSA. Cicatrization: current concepts and auxiliary resources - Part I. An Bras Dermatol. 2003;72:393-410.

63. Townsend CM. Wound healing In Sabiston's: textbook of surgery - the biological basis of modern surgical practice Saunders. 18th ed. Philadelphia: Elsevier; 2008.

64. Pimentel ER. Matriz extracelular. In: A Célula. 1st ed. Brasil: Editora Manole; 2001. p. 217.

65. Alberts B, Johnson A, Lewis J, Raff M, Roberts K, Walter P. Biologia molecular da célula. 4th ed. Porto Alegre: Artmed; 2004.

66. Balbino CA, Pereira LM, Curi R. Mecanismos envolvidos na cicatrização: uma revisão. Braz J Pharm Sci. 2005;41:27-51.

67. Valko M, Leibfritz D, Moncola J, Cronin MTD, Mazura M, Telser J. Free radicals and antioxidants in normal physiological functions and human disease. Int J Biochem Cell Biol. 2007:39:44-84.

68. Simões CMO, Schenkel EP, Gosmann G, Mello JCP, Mentz LA, Petrovick PR. Farmacognosia, da planta ao medicamento. 5th ed. Florianópolis: Ed. UFRGS; 2004.

69. Broughton $\mathrm{G}$, Janis JE, Attinger $\mathrm{CE}$. The basic science of wound healing. Plast Reconstr Surg. 2006;117:12-34.

70. Ozgen U, Ikbal M, Hacimuftuoglu A, Houghton PJ, Gocer F, Dogan H, et al. Fibroblast growth stimulation by extracts and compounds of Onosma argentatum roots. J Ethnopharmacol. 2006;104:100-3.

71. Dorneles D, Wouk AF, Pontarolo R, Oliveira AB. Efeito de Aloe vera Linne sobre a cicatrização de feridas de pele em coelhos. Visão Acadêmica. 2003; 4:39-46.

72. Martins VL, Caley M, O'Toole EA. Matrix metalloproteinases and epidermal wound repair. Cell Tissue Res. 2013;351:255-68.

73. Branco Neto MLC, Ribas Filho JM, Malafaia O, Oliveira Filho MA, Czeczko NG, Aoki S, et al. Avaliação do extrato hidroalcoólico de Aroeira (Schinus terebinthifolius Raddi) no processo de cicatrização de feridas em pele de ratos. Acta Cir Bras. 2006;21:17-22.

74. Souza DW, Machado TSL, Zoppa ALV, Cruz RSF, Gáraque AP, Silva LCLC. Ensaio da aplicação de creme a base de Triticum vulgare na cicatrização de feridas cutâneas induzidas em eqüinos. Rev Bras Plantas Med. 2006:8:9-13.

\section{Submit your next manuscript to BioMed Central and we will help you at every step:}

- We accept pre-submission inquiries

- Our selector tool helps you to find the most relevant journal

- We provide round the clock customer support

- Convenient online submission

- Thorough peer review

- Inclusion in PubMed and all major indexing services

- Maximum visibility for your research

Submit your manuscript at www.biomedcentral.com/submit

C Biomed Central 